\title{
CRYPTOCURRENCIES OR CAPITAL MARKETS. COMPARATIVE ANALYSIS OF INVESTMENT EFFICIENCY IN 2011-2020
}

\author{
KRYPTOWALUTY CZY RYNKI KAPITAŁOWE. ANALIZA PORÓWNAWCZA \\ EFEKTYWNOŚCI INWESTYCJI W LATACH 2011-2020
}

https://doi.org/10.34739/zn.2021.56.04

\author{
Sylwester Kozak ${ }^{1}$, Seweryn Gajdek ${ }^{2}$ \\ ${ }^{1}$ Poland, Warsaw University of Life Sciences, Department of Economics and Economic Policy \\ sylwester_kozak@sggw.edu.pl, ORCID: 0000-0001-9485-6704 \\ ${ }^{2}$ Poland, Warsaw University of Life Sciences, Department of Economics and Economic Policy \\ seweryn_gajdek@sggw.pl, ORCID: 0000-0001-5199-6758
}

\begin{abstract}
Cryptocurrencies have become an important element of the global financial system and a frequent investment tool in the last decade. The aim of this paper is to compare the efficiency of investments in the cryptocurrency market with investments in global capital markets. The study used the quotations of the analyzed instruments in the years 2011-2020. The investment efficiency was estimated using Sharpe and Sortino ratios. Research has shown that investments in cryptocurrencies were the most effective. They brought, on average, the highest daily rates of return, but on the other hand, they were characterized by the highest risk. Such a result could have been significantly influenced by the widespread persistence of ultra-low interest rates and a decline in the attractiveness of debt securities. The best results were obtained for investments in bitcoin and ethereum, which have the largest share of cryptocurrency market capitalization.
\end{abstract}

Key words: cryptocurrencies, investments, financial markets, investment efficiency

\begin{abstract}
Streszczenie: Kryptowaluty stały się w ostatnim dziesięcioleciu istotnym elementem globalnego systemu finansowego i częstym narzędziem inwestycyjnym. Celem pracy było porównanie poziomów efektywności inwestycji na rynku kryptowalut z inwestycjami na globalnych rynkach kapitałowych. W badaniu wykorzystano notowania analizowanych instrumentów w latach 2011-2020. Efektywność inwestycji oszacowano przy użyciu wskaźników Sharpe'a i Sortino. Badania wykazały, że inwestycje w kryptowaluty były najbardziej efektywne. Przyniosły one średnio najwyższe dzienne stopy zwrotu, ale z drugiej strony charakteryzowały się najwyższym ryzykiem. Na taki wynik mogło mieć istotny wpływ powszechne utrzymywanie się ultraniskich stóp procentowych i obniżenie atrakcyjności w dłużne papiery wartościowe. Najlepsze wyniki stwierdzono dla inwestycji w bitcoina i ethereum, posiadające największe udziały w kapitalizacji rynku kryptowalut.
\end{abstract}

Słowa kluczowe: kryptowaluty, inwestycje, rynki finansowe, efektywność inwestycji

\section{Introduction}

The dynamic development of the cryptocurrency market makes it more and more popular not only due to the unique technology and range of usability that supports it, but also due to growing yields. However, the opinions of economists and academics on this matter are strongly divided. On the one hand, supervisory offices send warning signals, especially to private individuals, against succumbing to the vision of obtaining quick extraordinary profits, as well as against creating a speculative bubble on cryptocurrencies (Geuder,
Kinateder and Wagner, 2019; Enoksen, Landsnes, Lučivjanská and Molnár, 2020; UKNF, 2021). On the other hand, many people see BTC and other cryptocurrencies as an effective tool for storing value (Corbet, Hou, Hu, Larkin and Oxley, 2020; Baur and Dimpf, 2021).

In many cases, treating cryptocurrencies only as a speculative tool is not fully justified, as it ignores many positive aspects of the functioning of cryptocurrencies, including their use in trade or international fund transfers. An important aspect is also the contribution of cryptocurrencies to the development of electronic money creation 
technology, widely accepted and implemented by central banks. However, the cryptocurrency system clearly differs from the current vision of the financial system. The decentralization of the functioning of money underlying this system, the lack of a hierarchical structure, as well as the limited and finite supply of coins should be the subject of careful analysis. Regardless of the problem of excessive anonymity of transactions carried out in this system, an important problem is the assessment of the efficiency of investments in cryptocurrencies. This is due to the dynamically increasing investment activity of cryptocurrency market participants.

The rest of the article is structured as follows. The next section presents the aim of the study, and the following sections: analysis of the literature on the subject, research methods, assessment of the global macroeconomic situation as well as research results and their discussion. The whole research is summarized in the conclusions.

\section{The aim, materials and research methods}

The aim of this article is to estimate and compare the level of efficiency of investments in selected cryptocurrencies (bitcoin - BTC, litecoin - LTC and ethereum $-E T H$ ) in relation to selected investment instruments in 2011-2020. The choice of three cryptocurrencies resulted, among others, from their high capitalization, highest shares in the cryptocurrency market and longest operating histories. The benchmark instruments come from the capital market and are indices of the largest global capital exchanges in London (index: FTSE 250), Milan (Euronext 100), New York (DIJA) and Shanghai (SSEC). The shares in these indices represent the largest international companies with links to business partners in many countries around the world. Therefore, the share prices of these companies reflect economic developments of a global nature. The limited number of analyzes carried out on the efficiency of investments in cryptocurrencies makes the results of our research important for the appropriate assessment of the issue of investing in cryptocurrencies.

The temporal scope of the study is determined, among others, by the date when BTC started its quotation on the market. The data for the study come from cryptocurrency quotes and stock exchange indices published by the Thomson Reuters agency. Taking into account the significant volatility of the quotations of the analyzed instruments, the investment efficiency was determined using the Sharpe ratio and the Sortino ratio, taking into account the daily logarithmic rate of return and the deviation and semi-standard deviation of daily logarithmic rates of return.

\section{Literature review}

Assessment of the efficiency of investments in cryptocurrencies is not a very common subject of research: a relatively frequent area of interest is the assessment of the benefits that can be derived by cryptocurrencies in the process of diversifying investment portfolios. Among others, Hung, Ly, Lu, Hoang and Wong (2021), comparing the efficiency of portfolios diversified with the use of gold and with the use of BTC in the years 2010-2020, showed that gold allows to lower the overall risk of the portfolio more than BTC. The portfolio diversified by BTC was characterized by greater volatility in daily rates of return, but brought higher investment returns. This means that investors with higher risk aversion can diversify their investment portfolio using gold. Conversely, investors with less risk aversion can diversify their portfolios with BTC and expect higher returns. Okorie (2020) reached similar conclusions by examining the diversification possibilities of BTC and shares from the S\&P500 stock index in 2016-2018. He stated that BTC is a profitable investment vehicle, while at the same time well diversifying equity portfolios.

In turn, Garcia-Jorcano and Benito (2020) confirmed that in 2011-2019, BTC served as an effective tool for diversifying investment portfolios composed of stocks belonging to the following indices: S\&P500 (USA), STOXX50 (European Union), NIKKEI (Japan), CSI300 (China) and HSI (Hong Kong). Similar diversification properties of BTC were noticed by Kang, Yoon and Bekiros (2020), who indicated that in 2011-2016 the daily rates of return on BTC were negatively correlated with the returns on the S\&P500 stock index, US treasury bonds and gold. Investing in BTC can improve the diversification and efficiency of investment portfolio risk management and capital allocation. Qarni and Gulzar (2021) noted similar diversification properties of BTC in combination with the US, Australian and Canadian dollars, euro, British pound and Japanese yen. In addition, Hong (2017) noted that BTC could be an alternative investment vehicle in addition to its diversification properties. On the other hand, Stensås, Nygaard, Kyaw and Treepongkaruna (2019), analyzing investments in the currencies of BRICS countries (Brazil, Russia, India, China, South Africa) and precious metals in 2011-2018, found that BTC is an effective tool for risk diversification in portfolios containing precious metals. The inclusion of BTC in the currency portfolios of developing countries, however, does not bring the appropriate diversification effects. 
In contrast, Wang, Zhang, Li and Shen (2019) examined two possible functions of BTC, i.e. diversifying other stock portfolios and storing value. They found that the analyzed portfolio of stocks from 30 countries was not effectively diversified by BTC. However, a long-term investment in BTC paid off, which makes it possible to conclude that cryptocurrencies can be classified as a "safe haven" investment.

On the other hand, Majdoub, Sassi and Bejaoui (2021), based on the analysis of the daily rates of return on BTC and platinum, gold, silver, copper and wheat in 2013-2018, concluded that the disturbances in the BTC market had an impact on the level of prices on commodity exchanges. They found no significant response in the opposite direction, i.e. the impact of disturbances in commodity exchanges on the level of BTC prices. However, they showed that strong trend reversals in one market could potentially cause equally strong changes in trends in the other market.

Baur, Lee and Hong (2018) found that currently BTC is more frequently used as a speculative investment vehicle comparing to global currencies. Aslanidis, Bariviera and Martinez-Ibanez (2019) in their work confirmed this claim and also pointed out that BTC is not currently capable of performing the function of storing value, which is required of a standard currency. In turn, Gronwald (2019), while examining the level of the BTC exchange rate in 2011-2019, stated that this cryptocurrency can be used as a profitable investment tool, however, it carries a significant risk, which is the result of a significant sensitivity of BTC to external disturbances.

One of the few works assessing the efficiency of the cryptocurrency investments is the analysis of Wyderka and Saganowski (2018). They compared the efficiency of investments in BTC with the efficiency of investments on the Warsaw Stock Exchange and found that cryptocurrencies are more profitable instruments than shares of Polish companies. At the same time, they indicated that BTC is an unstable investment. The measures applied in the research, i.e. the standard deviation of the rate of return and the coefficient of variation of the rate of return, did not, however, give an unambiguous answer as to which investment is burdened with a higher risk. On the other hand, Michalczyk (2018), when examining the relationship between the level of profitability and risk in investing in the most important cryptocurrencies, stated that the risk of investing is very high and the level of expected income varies significantly.

It is difficult to predict the future of the cryptocurrencies' market due to the dynamically developing technology and legislative regulations related to these instruments. Decentralization of payments makes difficult to monitor the developments of the market. However, there are many indications that from an investment point of view, cryptocurrencies will remain an attractive asset in the next few years. The issue that distinguishes them from other assets is the limited supply of many of cryptocurrencies as well as functions that are not available with traditional money. These include smart contracts or decentralized financial applications. Due to the predetermined and unchanging supply of BTC and the level of its emission, it is possible to approximate the future price of this currency based on the stock-to-flow model, which predicts the BTC price in mid-2025 at over 800,000 dollars. The chart "Bitcoin Logarithmic Growth Curves" also points to further increases in the BTC rate in the long term, assuming that the growth rate of the demand for this cryptocurrency remains unchanged. The authors of both models are partially anonymous, however their works are available at www.lookintobitcoin.com. Similar forecasts are impossible to make for ETH, because the maximum level of emissions of this cryptocurrency is undefined, as well as for LTC due to the weakening market power.

\section{The global macroeconomic situation}

The situation of the most important economies and financial markets in the world at the beginning of the second decade of the 21st century was significantly influenced by the negative effects of the global financial crisis of 2007-2009 (GFC). Aid measures initiated by central banks and public authorities have significantly transformed the current vision of the financial system. The high level of public debt and the close to zero reference interest rates of central banks have become permanent elements of the financial profile of most countries in the world. In many cases this has led to the reoccurrence of local financial crises. As a result, in 2011-2020 the growth rate of the most important world economies was diversified (Table 1). In addition to the GFC, its amount was significantly affected by the crisis of excessive debt of public finances in the euro area countries in 2011-2013, the slowdown in economic growth in China in 2015-2016 and the outbreak of the COVID-19 pandemic in 2020.

The conduct of an easy monetary policy by central banks and the launch of the purchase of securities (the quantitative easing (QE) program) contributed to economic growth in most countries of the world and to increases in stock prices on equity exchanges. As a result, the level of longterm interest rates, represented by the interest rate 
of 10-year treasury bonds, in the euro area countries had a downward trend, reaching negative values in the last years of the decade (Table 2). However, the persistently low interest rate on all debt instruments made them less attractive to investors and caused a shift of some investment capital from the bond market to the stock market and the cryptocurrency market.

Table 1. GDP growth of major world economies in 2011-2020 (\%)

\begin{tabular}{lcccccccccc}
\hline Country & $\mathbf{2 0 1 1}$ & $\mathbf{2 0 1 2}$ & $\mathbf{2 0 1 3}$ & $\mathbf{2 0 1 4}$ & $\mathbf{2 0 1 5}$ & $\mathbf{2 0 1 6}$ & $\mathbf{2 0 1 7}$ & $\mathbf{2 0 1 8}$ & $\mathbf{2 0 1 9}$ & $\mathbf{2 0 2 0}$ \\
\hline France & 2.7 & 1.9 & -0.2 & 1.1 & 1.3 & 1.6 & 2.1 & 2.8 & 1.9 & -7.2 \\
Germany & 3.5 & 2.2 & 0.2 & 1.9 & 1.8 & 1.5 & 2.1 & 3.1 & 0.8 & -4.1 \\
Great Britain & 1.5 & 1.8 & 1.9 & 2.8 & 2.5 & 2.2 & 1.9 & 1.6 & 1.4 & -6.5 \\
China & 10.2 & 8.5 & 8.6 & 7.8 & 7.4 & 7.1 & 7.4 & 7.2 & 6.8 & 2.1 \\
Japan & -0.8 & 1.0 & 0.1 & 3.5 & 0.1 & 1.6 & 1.2 & 2.0 & 0.2 & -4.5 \\
USA & 1.8 & 2.0 & 1.7 & 2.0 & 2.9 & 2.0 & 2.1 & 2.7 & 2.2 & -3.2 \\
Euro area & 1.9 & 0.9 & 0.8 & 2.2 & 1.7 & 3.1 & 2.9 & 0.4 & -4.1 & -3.8 \\
UE & 2.2 & 0.8 & 1.1 & 1.8 & 2.2 & 2.4 & 2.9 & 3.1 & 1.8 & -4.8 \\
\hline
\end{tabular}

Source: own elaboration based on Thomson Reuters data.

Table 2. The level of long-term interest rates (\%)

\begin{tabular}{lllllllllll}
\hline Country & $\mathbf{2 0 1 1}$ & $\mathbf{2 0 1 2}$ & $\mathbf{2 0 1 3}$ & $\mathbf{2 0 1 4}$ & $\mathbf{2 0 1 5}$ & $\mathbf{2 0 1 6}$ & $\mathbf{2 0 1 7}$ & $\mathbf{2 0 1 8}$ & $\mathbf{2 0 1 9}$ & $\mathbf{2 0 2 0}$ \\
\hline France & 3.01 & 2.44 & 2.41 & 0.90 & 0.99 & 0.68 & 0.79 & 0.71 & -0.02 & -0.34 \\
Germany & 1.95 & 1.31 & 1.94 & 0.50 & 0.63 & 0.21 & 0.42 & 0.21 & -0.25 & -0.58 \\
Great Britain & 1.98 & 2.12 & 3.09 & 1.72 & 1.93 & 1.34 & 1.20 & 1.28 & 0.75 & 0.20 \\
China & 3.55 & 3.53 & 4.57 & 3.65 & 2.84 & 3.06 & 3.92 & 3.15 & 3.16 & 3.18 \\
Japan & 1.35 & 1.00 & 0.72 & 0.62 & 0.58 & 0.38 & 0.19 & 0.16 & 0.04 & -0.05 \\
USA & 1.80 & 1.18 & 3.07 & 2.26 & 2.27 & 2.46 & 2.41 & 2.66 & 1.79 & 0.91 \\
\hline
\end{tabular}

Source: own elaboration based on Thomson Reuters data.

The prolonged period of low or even negative interest rates contributed to the increase in demand for cryptocurrencies, especially BTC. In the period from entering the market to the end of 2020 , the prices of individual cryptocurrencies increased several dozen or even several hundred times. On the other hand, the quotations of shortterm debt instruments dropped significantly throughout the decade.

The cryptocurrency and stock exchange indices analyzed in the study assumed variable values. The distribution of cryptocurrency quotes can be divided into several periods with their dynamic increases and decreases. In the case of cryptocurrencies, these periods were in 2017-2018 and 2019.
However, the moment of the outbreak of the COVID-19 pandemic in March 2020 only for a few weeks weakened the strong upward trends in the quotations of all cryptocurrencies. In the case of stock exchanges, the upward trend is characteristic and the strong correlation of the DJIA, Euronext and FTSE 250 indices. On the contrary, the performance of the Shanghai SSEC stock exchange index was relatively stable, except for the period of weakening dynamics of the Chinese economy in 2015-2016. 

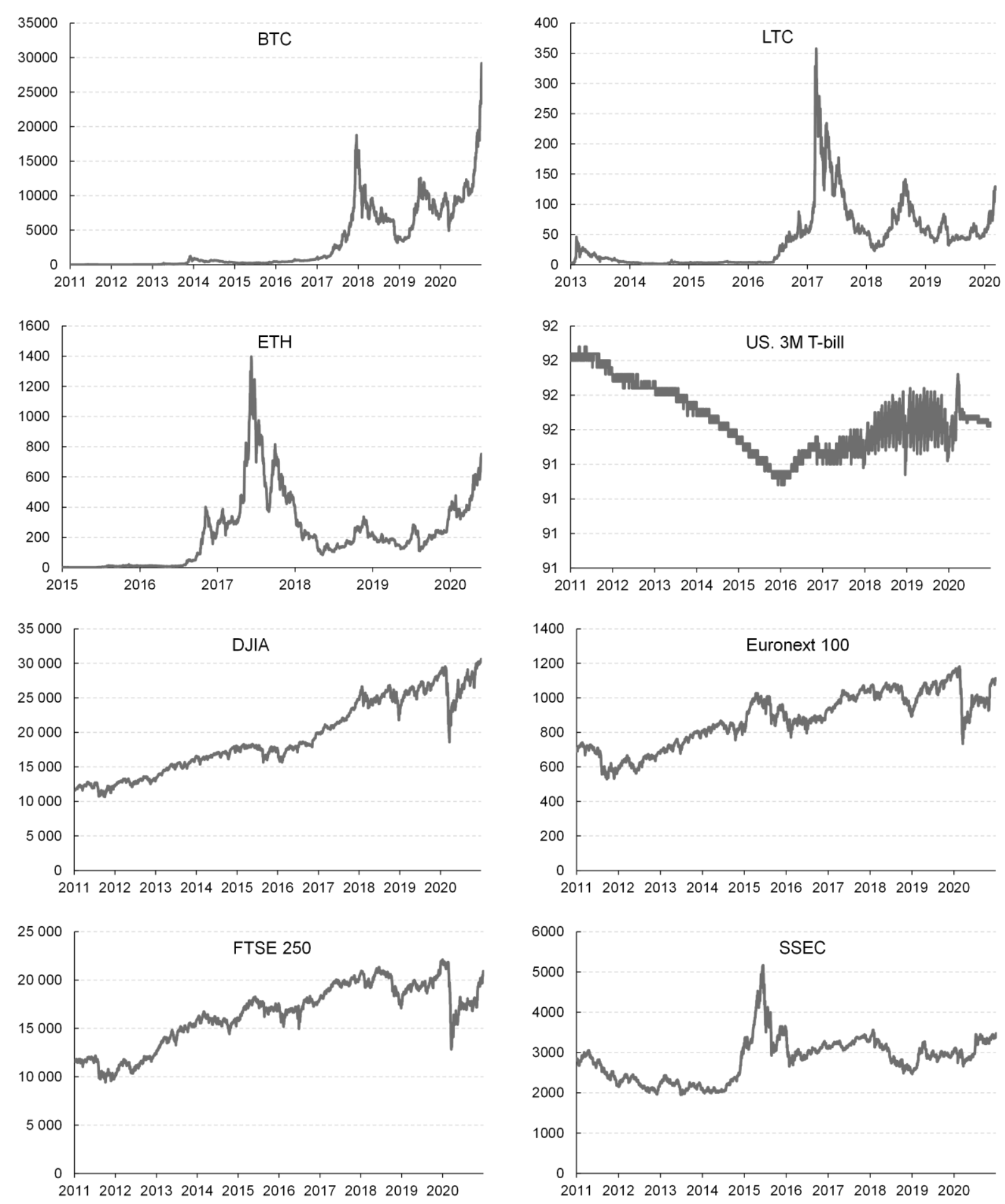

Figure 1. Quotations of selected investment instruments in 2011-2020 Notes: BTC, LTC, ETH in USD; US. 3M T-bill, DJIA, Euronext 100, FTSE 250, SSEC in points.

Source: own elaboration based on Thomson Reuters data.

\section{Materials and methods}

The first stage of the research was to determine the daily logarithmic rates of return on investments in cryptocurrencies and the stock indices selected for the study according to the following formula:

$$
r_{p t}=\ln \ln \left(V_{p t}\right)-\ln \left(V_{p t-1}\right)=\ln \ln \left(\frac{V_{p t}}{V_{p t-1}}\right)
$$

where: In is the natural logarithm, $V_{p t}$ and $V_{p t-1}$ respectively, the value of the instrument $p$ on $t$ and 
$\mathrm{t}-1$. In the next stage, the risk level of investments in selected instruments was estimated. Taking into account the methods used in previous studies, incl. Wyderka and Saganowski (2018), the following measures were selected for risk assessment: standard deviation (SD) and semistandard deviation (SE) of daily rates of return calculated according to the following formulas:

$$
\begin{aligned}
S D & =\sqrt{\frac{1}{n-1} \sum_{t=1}^{n}\left[r_{p t}-\bar{r}_{p}\right]^{2}} ; \\
S E & =\sqrt{\frac{1}{n-1} \sum_{t=1}^{n}\left[\left(r_{p t}-\overline{r_{p}}\right)^{-}\right]^{2}}
\end{aligned}
$$

where $r_{p t}, r_{p}$ denote, respectively, the daily rate of return on investment in the $p$ instrument on day $t$ and the average for the given period of the daily rates of return, $\mathrm{n}$ - number of days in the analyzed period. The sign "-" indicates that only those cases are considered for the purpose of determining the standard deviation where $r_{p t}$ is less than $\overline{r_{p}}$. The rationale for adopting an asymmetric risk rating system is that investors only find it unfavorable when the portfolio's actual rate of return is lower than its average value.

In the last stage of the study, the efficiency levels of investments in selected instruments were determined using the Sharpe ratio and the Sortino ratio. The first measure is a frequently used tool for assessing the efficiency of investments in the capital market, as well as in the cryptocurrency market (Baur, Cahill, Godfrey and Liu, 2019; Damianov and Elsayed, 2020; Rehman, 2020). It is calculated according to the following formula:

$$
W S=\frac{r_{p}-r_{f}}{S D}
$$

where: $S D$ is the standard deviation of the daily rates of return on investment, $r_{p}$ and $r_{f}$ are the average daily rates of return for a given investment and risk-free instrument over the period, respectively. In the study, 3-month US Treasury bills (US. 3M T-bill) were adopted as a risk-free instrument. The Sharpe ratio $(1966,1975)$ is often defined as the value of the premium for taking a total risk unit measured by the standard deviation from the average rate of return. Higher values of the Sharpe ratio indicate a higher quality of investment portfolio management, i.e. that at the same risk level, investors achieve higher rates of return or that the same profitability is achieved by a portfolio that takes on a lower investment risk.

The Sortino ratio was constructed on the basis of the Sharpe ratio by Sortino and Price (1994). It measures the investment risk in an asymmetric way (SE semi-standard deviation), and the rate of return of the risk-free investment is replaced by $m$ - the minimum rate of return acceptable to the investor. It is described by the following formula:

$$
S=\frac{\overline{r_{p}}-m}{S E}
$$

The authors of the $S$ ratio suggest that the minimum acceptable rate of return $m$ should be equal to $0 \%$ or to the value of the rate of return from the market portfolio, e.g. represented by a selected stock index. In the research, $0 \%$ was assumed as the value of $m$.

\section{Results and discussion}

The first step in the calculations was to estimate the daily logarithmic rates of return for individual instruments. In the case of all instruments, the values of the rates of return were highly volatile, although investments in cryptocurrencies were characterized by the highest volatility. They achieved both the highest and the lowest average daily rates of return $(1.25 \%$ - ETH in $2017 ;-0.59 \%$ - LTC in 2018). The average values of daily rates of return throughout the analyzed period obtained from investments in cryptocurrencies ranged from $0.32 \%$ (BTC) to $0.43 \%$ (LTC). These values were many times higher than in the case of stock exchange indices, whose average for the entire period ranged from $0.006 \%$ (SSEC) to $0.027 \%$ (DJIA).

In the next step, the risk level was estimated using two measures: standard deviation (SD) and semi-standard deviation (SE) of daily rates of return. The results showed that investments in cryptocurrencies were characterized by a much higher level of risk than investments in the largest global exchanges. In the case of cryptocurrencies, the highest levels of risk were recorded in the first years of their operation on the market, while in stock exchanges in 2020 , i.e. the year of the outbreak of the COVID-19 pandemic. The average annual values of the SD indicator for cryptocurrencies ranged from $4.50 \%$ (BTC) to $7.42 \%$ (LTC), while for stock exchanges from $0.80 \%$ (DJIA) to $1.04 \%$ (SSEC). Also, the risk measured by the SE indicator turned out to be the highest in the case of investments in cryptocurrencies (from $3.00 \%$, BTC to $4.22 \%$, LTC) and many times lower in the case of capital exchanges (from $0.58 \%$, DJIA to $0.77 \%$, SSEC).

The last stage of the calculations was to estimate the investment efficiency using two measures: Sharpe ratio and Sortino ratio, in the version for $m=0 \%$ (Table 3 ). The results of the estimation indicate that in the case of investments 
in cryptocurrencies, despite the high level of risk noted in the first years of their operation on the market, they obtained high efficiency values at that time. Other periods of high efficiency were the years 2017 and 2020, i.e. periods of strong increases in cryptocurrency prices (Fig. 1). On the other hand, in the case of investments on stock exchanges, the highest efficiency was achieved in 2013, 2017 and 2019. Also in this case, higher efficiency values can be attributed to the constant upward trend in stock exchange indices (Fig. 1).

Table 3. Investment efficiency measured by Sharpe and Sortino ratios in 2011-2020 (\%)

\begin{tabular}{|c|c|c|c|c|c|c|c|c|c|c|}
\hline $\begin{array}{l}\text { Investment } \\
\text { instrument }\end{array}$ & 2011 & 2012 & 2013 & 2014 & 2015 & 2016 & 2017 & 2018 & 2019 & 2020 \\
\hline \multicolumn{11}{|c|}{ Sharpe ratio } \\
\hline BTC & 8.76 & 8.71 & 14.96 & -6.69 & 2.37 & 9.18 & 15.89 & -9.00 & 4.89 & 10.43 \\
\hline LTC & & & 14.53 & -10.19 & 1.04 & 2.16 & 13.37 & -9.89 & 1.78 & 6.00 \\
\hline ETH & & & & & 1.46 & 8.64 & 17.74 & -8.41 & -0.19 & 9.88 \\
\hline DJIA & 1.35 & 3.14 & 12.12 & 3.53 & -0.72 & 5.19 & 17.61 & -1.71 & 8.48 & 0.97 \\
\hline FTSE 250 & -3.48 & 7.12 & 10.77 & 0.44 & 3.37 & 1.02 & 9.37 & -7.26 & 9.87 & -1.14 \\
\hline Euronext 100 & -3.18 & 4.15 & 6.49 & 1.32 & 1.90 & 0.79 & 5.60 & -4.79 & 9.25 & -0.63 \\
\hline SSEC & -7.06 & 0.97 & -2.02 & 13.05 & 1.24 & -3.00 & 3.89 & -7.63 & 5.93 & 3.29 \\
\hline \multicolumn{11}{|c|}{ Sortino ratio } \\
\hline BTC & 13.67 & 12.70 & 23.93 & -9.78 & 2.81 & 14.27 & 25.82 & -11.32 & 7.43 & 14.81 \\
\hline LTC & & & 27.43 & -9.08 & 1.25 & 2.55 & 25.56 & -13.29 & 2.51 & 8.20 \\
\hline ETH & & & & & 3.57 & 13.51 & 31.32 & -11.06 & -0.53 & 12.92 \\
\hline DJIA & 0.80 & 2.62 & 16.18 & 2.85 & -2.47 & 5.62 & 25.40 & -3.35 & 10.18 & 0.75 \\
\hline FTSE 250 & -5.59 & 8.85 & 14.07 & -1.25 & 2.96 & 0.23 & 10.76 & -10.86 & 13.83 & -2.18 \\
\hline Euronext 100 & -5.16 & 4.73 & 7.87 & 0.29 & 1.59 & 0.00 & 6.18 & -7.63 & 11.32 & -1.43 \\
\hline SSEC & -10.24 & 0.05 & -3.94 & 19.47 & 1.05 & -4.44 & 2.90 & -10.69 & 7.48 & 3.45 \\
\hline
\end{tabular}

Source: own elaboration based on Thomson Reuters data.
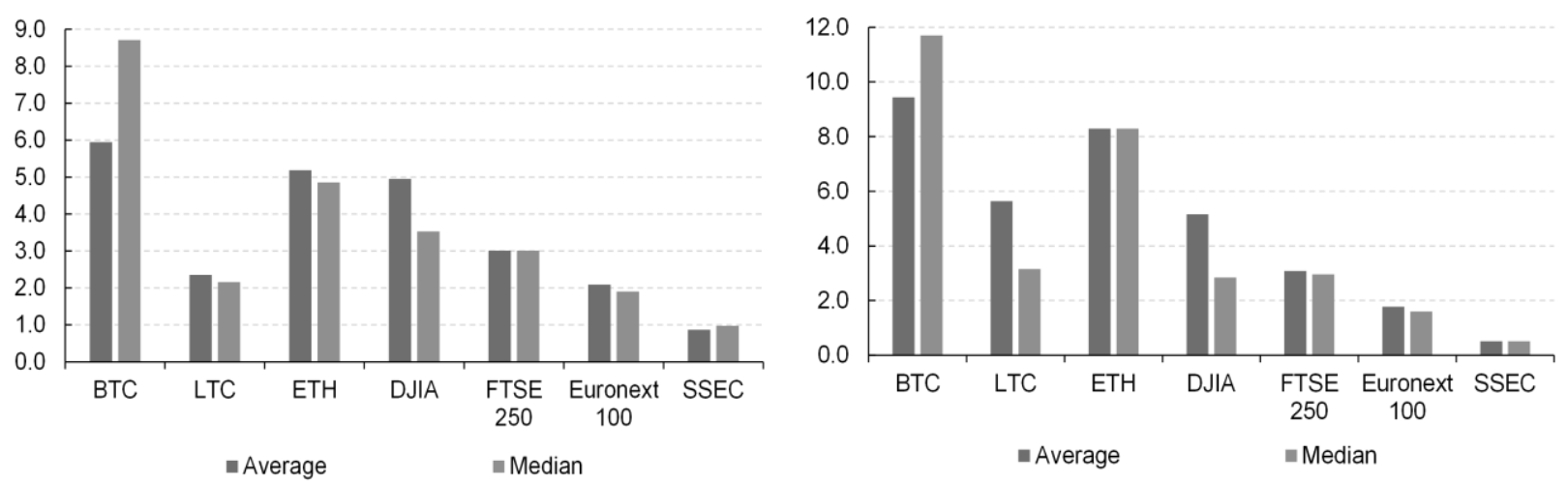

Figure 2. Average and median investment efficiency in 2011-2020 measured by the Sharpe ratio (\%) (left panel) and the Sortino ratio (\%) (right panel)

Source: own elaboration based on Thomson Reuters data.

The average for the entire period of the efficiency of investments in cryptocurrencies turned out to be higher than the efficiency of investments on global capital exchanges. Investments in BTC and ETH turned out to be the most effective - as measured by both the Sharpe ratio and the Sortino ratio. Such a distribution of efficiency measures could have been significantly influenced by the high market capitalization of these cryptocurrencies. At the end of 2020, BTC and ETH had the highest market shares of $70 \%$ and $11 \%$ respectively. 
Investments in the US and UK markets turned out to be the most effective investments in capital markets. The economies of these countries enjoyed relatively steady and high growth (with the exception of 2020, when the COVID-19 pandemic broke out), affecting the prices of stocks listed on exchanges in New York and London. In turn, low efficiency in investment in European stocks (Euronext 100) was associated with unfavorable conditions of the euro area economy, which was strongly adversely affected by the GFC as well as the crisis of public finances and the COVID-19 crisis in 2020. The lack of a clear upward trend on the Shanghai stock exchange may be the reason why the investments made here turned out to be the least effective among the analyzed instruments.

\section{Conclusions}

Cryptocurrencies, being an independent system, have become an important element of the global financial system. They are increasingly used as a tool for conducting international payments and an investment tool. The complex system of their operation and the lack of regulations cause that investments in cryptocurrencies are characterized by a much higher risk comparing to other assets.

\section{References}

Aslanidis, N., Bariviera, A.F., Martinez-lbanez, O. (2019). An analysis of cryptocurrencies conditional cross correlations. Finance Research Letters (31), 130-137. DOI: 10.1016/ j.frl.2019.04.019.

Baur, D.G., Cahill, D., Godfrey, K., Liu, Z.F. (2019). Bitcoin time-of-day, day-of-week and month-ofyear effects in returns and trading volume. Finance Research Letters (31), 78-92. DOI: 0.1016/j.frl.2019.04.023.

Baur, D.G., Dimpf, T. (2021). The volatility of Bitcoin and its role as a medium of exchange and a store of value. Empirical Economics. DOI: 10.1007/s00181-020-01990-5.

Baur, D.G., Lee, A.D., Hong, K. (2018). Bitcoin: medium of exchange or speculative assets? Journal of International Financial Markets, Institutions and Money (54), 177-189. DOI: 10.1016/j.intfin.2017.12.004.

Corbet, S., Hou, Y.G., Hu, Y., Larkin, Ch., Oxley, L. (2020). Any port in a storm: Cryptocurrency safe-havens during the COVID-19 pandemic. Economics Letters (194). DOI: 10.1016/ j.econlet.2020.109377.

Damianov, D.S., Elsayed, A.H. (2020). Does Bitcoin add value to global industry portfolios? Economics Letters, Elsevier (191C). DOI: 10.1016/j.econlet.2019.108935.
In addition to high risk, investments in cryptocurrencies are also characterized by high rates of return. The levels of risk and rates of return are many times higher than in the case of investments on global capital exchanges.

However, high profitability makes that the efficiency of investments in cryptocurrencies in 2011-2020 was, on average, higher than the efficiency of investments on global capital exchanges. Investments in high-capitalization cryptocurrencies, i.e. BTC and ETH, were characterized by the highest efficiency.

The persistence of the ultra-low interest rate environment could have had a significant impact on the high efficiency of investments in cryptocurrencies. They lowered the profitability of investments in debt securities, primarily treasury bonds, and contributed to the transfer of capital, inter alia to the cryptocurrency market. It could be one of the reasons why, despite the deep crisis caused by the COVID-19 pandemic, the efficiency of investments in cryptocurrencies has achieved such high levels. However, dynamic changes in the technology used and in regulations introduced in many countries make it difficult to predict the further development of the cryptocurrency market.

Enoksen, F.A., Landsnes, Ch.J., Lučivjanská, K., Molnár P. (2020). Understanding risk of bubbles in cryptocurrencies. Organisation (176), 129-144. DOI: 10.1016/j.jebo.2020.05.005.

Garcia-Jorcanoa, L., Benito, S. (2020). Studying the properties of the Bitcoin as a diversifying and hedging asset through a copula analysis: Constant and time-varying. Research in International Business and Finance (54C). DOI: 10.1016/j.ribaf.2020.101300.

Geuder, J., Kinateder, H., Wagner, N.F. (2019). Cryptocurrencies as financial bubbles: The case of Bitcoin. Finance Research Letters (31). DOI: 10.1016/j.frl.2018.11.011.

Global Market Data - Reuters.com, https://www.reuters.com/markets/globalmarket-data (access: 21.05.2021).

Gronwald, M. (2019). Is Bitcoin a Commodity? On price jumps, demand shocks, and certainty of supply. Journal of International Money and Finance (97), 86-92. DOI:10.1016/j.jimonfin. 2019.06.006.

Hong, K. (2017). Bitcoin as an alternative investment vehicle. Information Technology and Management (18), 265-275. DOI: 10.1007/s10799-016-0264-6.

Hung, P.K., Ly, S., Lu, R., Hoang, T.H.V., Wong, W.K. (2021). Is Bitcoin a better portfolio 
diversifier than gold? A copula and sectoral analysis for China. International Review of Financial Analysis (74), March. DOI: 10.1016/j.irfa.2021.101674.

Kang, S.H., Yoon, S.M., Bekiros, S., Uddin, G.S. (2020). Bitcoin as Hedge or Safe Haven: Evidence from Stock, Currency, Bond and Derivatives Markets. Computational Economics (56), 529-545. DOI:10.1007/s 10614-019-09935-6.

Look into bitcoin, https://www.lookintobitcoin.com (access: 06.09.2021).

Majdoub, J., Sassi, S.B., Bejaoui, A. (2021). Can fiat currencies really hedge Bitcoin? Evidence from dynamic short-term perspective. Decisions in Economics and Finance (2021). DOI: 10.1007/s10203-020-00314-7.

Michalczyk, W. (2018). Główne zależności pomiędzy poziomem dochodu, ryzyka i rozpowszechnienia najważniejszych kryptowalut [The main relationships between the level of income, risk and prevalence of the most important cryptocurrencies]. Studia Ekonomiczne Zeszyty Naukowe Uniwersytetu Ekonomicznego w Katowicach (372), 71-83.

Okorie, D. I. (2020). Did China's ICO ban alter the Bitcoin market? International Review of Economics \& Finance (69), 977-993. DOI: 10.1016/j.iref.2020.05.016.

Qarni, M.O., Gulzar, S. (2021). Portfolio diversification benefits of alternative currency investment in Bitcoin and foreign exchange markets. Financial Innovation (7). DOI: 10.1186/s40854-021-00233-5.

Rehman, M.U. (2020). Do Bitcoin and precious metals do any good together? An extreme dependence and risk spillover analysis. Resources Policy (68), 1-16. DOI: 10.1016/ j.resourpol.2020.101737.

Sharpe, W.F. (1966). Mutual fund performance. The Journal of Business (39.1), 119-138.

Shapre, W.F. (1975). Adjusting for risk in portfolio performance measurement. Journal of Portfolio Management (39.2), 29-34. DOI:10.3905/jpm. 1975.408513.
Sortino, F., Price, L. (1994). Performance Measurement in a Downside Risk Framework. Journal of Investing (30), 1519-1533.

Stensås, A., Nygaard, M.F., Kyaw, K., Treepongkaruna, S. (2019). Can Bitcoin be a diversifier, hedge or safe haven tool? Cogent Economics \& Finance (7.1), 1-21. DOI: 10.1080/23322 039.2019.1593072.

UKNF (2021). Ostrzeżenie Urzędu KNF o ryzykach związanych z nabywaniem oraz z obrotem kryptoaktywami [PFSA Office warning about the risks associated with the acquisition and trading of crypto assets]. Retrieved from: https://www.knf.gov.pl/knf/pl/komponenty/img/ Ostrzezenie_UKNF_o_ryzykach_zwiazanych_ z_nabywaniem_oraz_z_obrotem_kryptoaktyw ami_72241.pdf (access: 20.06.2021).

Wang, P., Zhang, W., Li, X., Shen, D. (2019). Is cryptocurrency a hedge or a safe haven for international indices? A comprehensive and dynamic perspective. Finance Research Letters (31.C), 1-18. DOI: 10.1016/j.frl.2019.04.031.

Wyderka, D., Saganowski, T. (2018). Efektywność inwestycji na rynku kryptowalut i inwestycji na rynku giełdowym - ujęcie porównawcze [The effectiveness of investments in the cryptocurrency market and investments in the stock market - a comparative approach]. Finanse i Prawo Finansowe (3.19), 67-77. 